\title{
ANALISIS DAN PEMODELAN PROTOTIPE SISTEM INFORMASI JADWAL KULIAH DENGAN ALGORITMA ABC (ARTIFICIAL BEE COLONY)
}

\author{
Mia Fitriawati ${ }^{1}$, Myrna Dwi Rahmatya ${ }^{2}$, Syahrul Mauluddin $^{3}$, Agus Nursikuwagus ${ }^{4}$ \\ ${ }^{1}$ Program Studi Sistem Informasi, Universitas Komputer Indonesia, miafitriawati@email.unikom.ac.id \\ ${ }^{2}$ Program Studi Sistem Informasi, Universitas Komputer Indonesia, myrna@email.unikom.ac.id \\ ${ }^{3}$ Program Studi Manajemen Informatika, Universitas Komputer Indonesia, syahrul.mauluddin@email.unikom.ac.id \\ ${ }^{4}$ Program Studi Manajemen Informatika, Universitas Komputer Indonesia, agus.nursikuwagus@email.unikom.ac.id
}

\begin{abstract}
ABSTRAK
Kegiatan penjadwalan kuliah di perguruan tinggi merupkan aktifitas rutin setiap semester yang sangat kompleks dan biasanya memerlukan waktu yang cukup lama. Semakin banyak aturan dan batasan maka semakin banyak jadwal yang harus dicek dan jika tidak teliti besar kemungkinan jadwal bentrok pun banyak terjadi. Kesulitan pembuatan jadwal kuliah ini dirasakan oleh bagian penjadwalan di program studi ilmu komunikasi, selain memerlukan waktu yang lama juga masih sering banyak jadwal yang bentrok. Untuk mengatasi permasalahan tersebut, sebagai tahap awal dilakukan analisis dan pemodelan sistem informasi jadwal kuliah dengan menggunakan algoritma ABC (Artificial Bee Colony). Metode penelitian yang digunakan mengacu kepada metode pengembangan sistem prototipe dan metode pendekatan berorientasi objek. Penelitian ini menghasilkan gambaran sistem dan model penerapan algoritma $\mathrm{ABC}$ pada sistem informasi jadwal kuliah.
\end{abstract}

\section{PENDAHULUAN}

Kegiatan penjadwalan kuliah pada setiap perguruan tinggi merupakan aktifitas rutin yang dilakukan setiap semester. Penjadwalan mata kuliah ini menjadi sangat rumit dan menguras pikiran karena banyaknya aturan dan batasan pada pembuatan jadwal yang harus dicek dan jika tidak teliti dengan baik, maka besar kemungkinan jadwal yang mengalami bentrok banyak terjadi.

Kesulitan dalam pembuatan jadwal kuliah ini dirasakan oleh bagian penjadwalan pada salah satu program studi, yaitu pada program studi ilmu komunikasi yang memiliki jumlah mahasiswa yang cukup banyak. Pada proses penjadwalan kuliah di program studi ilmu komunikasi dilakukan dengan cara memetakan kelas, dosen, ruang, hari, jam, dan matakuliah pada buku atau aplikasi excel, kemudian melakukan pengecekan satu persatu. Tentunya proses penjadwalan seperti itu membutuhkan waktu yang lama dan rentan terjadi kesalahan yang akan menyebabkan bentroknya jadwal perkuliahan.

Melihat permasalahan yang terjadi, dilakukan penelitian yaitu menganalisis dan membuat model sistem informasi jadwal kuliah dengan menerapkan Algoritma ABC (Artificial Bee Colony).

\section{TINJAUAN PUSTAKA}

\subsection{Definisi Sistem}

Sistem menurut Kendall merupakan "sekumpulan hal atau kegiatan atau elemen atau subsistem yang saling berkerjasama atau yang dihubungkan dengan cara-cara tertentu sehingga membentuk satu kesatuan untuk melaksanakan suatu fungsi guna mencapai suatu tujuan" [1].

Menurut Jack Febrian [2] "sistem adalah suatu jaringan kerja dari prosedur-prosedur yang saling berhubungan, berkumpul bersama-sama untuk melakukan suatu kegiatan atau untuk menyelesaikan suatu sasaran tertentu. Esensinya sistem terdiri dari pertama, komponen-komponen dalam sistem tersebut mencakup perangkat keras (hardware), perangkat lunak (software), prosedur (procedure), perangkat manusia (brainware), informasi (information) itu sendiri, dan kedua, fungsi-fungsi teknologi di dalamnya yaitu : input, proses (process), output, penyimpanan (storage) dan komunikasi (communication)". 
Menurut Hanif Al-Fatta [3] "Sistem dapat diartikan suatu kumpulan atau himpunan dari unsur atau variabel-variabel yang saling terorganisasi, saling berinteraksi, dan saling bergantung satu sama lain."

\subsection{Definisi Informasi}

Menurut Jack Febrian "Informasi merupakan keterangan, penerangan. Data yang telah diproses ke dalam suatu yang mempunyai arti bagi si penerima dan mempunyai nilai nyata dan terasa bagi keputusan saat itu atau keputusan mendatang" [2].

Menurut Jeperson Hutahaean "Informasi adalah data yang diolah menjadi bentuk yang lebih berguna dan lebih berarti bagi penerimanya" [4].

\subsection{Definisi Sistem Informasi}

Menurut Jack Febrian, "Sistem Informasi merupakan sistem yang menghasilkan informasi yang berguna. Suatu sistem di dalam suatu organisasi yang mempertemukan kebutuhan pengolahan transaksi harian, mendukung operasi, bersifat manajerial, dan kegiatan straregi dari suatu organisasi dan menyediakan pihak pihak luar tertentu dengan laporan-laporan yang diperlukan." [2].

Menurut Jeperson Hutahaean, "Sistem Informasi adalah sistem di dalam suatu organisasi yang mempertemukan kebutuhan pengelolalaan transaksi harian, mendukung operasi, bersifat manajerial, dan kegiatan strategi dari suatu organisasi dan menyediakan pihak luar tertentu dengan laporanlaporan yang dibutuhkan"[4].

\subsection{Definisi Penjadwalan Kuliah}

Menurut Eddy Herjanto, "Penjadwalan adalah pengaturan waktu dari suatu kegiatan operasi, yang mencakup kegiatan mengalokasikan fasilitas, peralatan maupun tenaga kerja, dan menentukan urutan pelaksanaan bagi suatu kegiatan operasi"'[5]. Adapun definisi kuliah dalam kamus besar bahasa Indonesia adalah "pelajaran yang diberikan di perguruan tinggi"'[6]. Berdasarkan definisi tersebut dapat diartikan penjadwalan kuliah adalah proses pengaturan waktu kuliah di sebuah perguruan tinggi.

\subsection{Algoritma ABC (Artificial Bee Colony)}

Algoritma ABC merupakan sebuah algoritma yang memodelkan kecerdasan kolektif lebah madu dalam mencari sumber makanan, yang terdiri dari 3 komponen esensial [7], yakni:

1. Food Sources: nilai atau kualitas dari suatu sumber makanan ditentukan oleh jaraknya dengan sarang lebah, banyaknya jumlah makanan, dan kemudahan dalam mengambil makanan tersebut.

2. Employed Foragers, merupakan lebah-lebah yang bertugas menyimpan informasi dari sumber makanan yang ditemukan.

3. Unemployed Foragers, merupakan lebah-lebah yang bertugas mencari sumber-sumber makanan yang dapat dieksploitasi. Terdapat 2 jenis dari Unemployed Foragers yaitu scouts dan onlookers.

Algoritma $\mathrm{ABC}$ dimulai dengan sebuah populasi yang terdiri dari kumpulan agen lebah. Berdasarkan tugasnya, agen lebah terbagi menjadi tiga jenis [7] yaitu:

1. Scout Bees yaitu lebah yang memiliki tugas untuk mencari secara acak lokasi-lokasi food source sekitar sarang. Informasi lokasi food source kemudian disampaikan ke agen lebah berikutnya yaitu Employed Bees.

2. Employed Bees yaitu agen lebah yang memiliki tugas langsung dengan food source yang telah ditemukan sebelumnya oleh Scout Bees. Employed Bees bertugas menyimpan informasi yang terkait dengan data setiap sumber makanan.

3. Onlooker Bees yaitu agen yang memliki tugas untuk melakukan pemilihan dan pengeksploitasian food source yang informasinya telah disimpan oleh Employed Bees. 


\subsection{Struktur Algoritma ABC}

Secara umumnya, struktur dari algoritma ABC [7] adalah sebagai berikut :

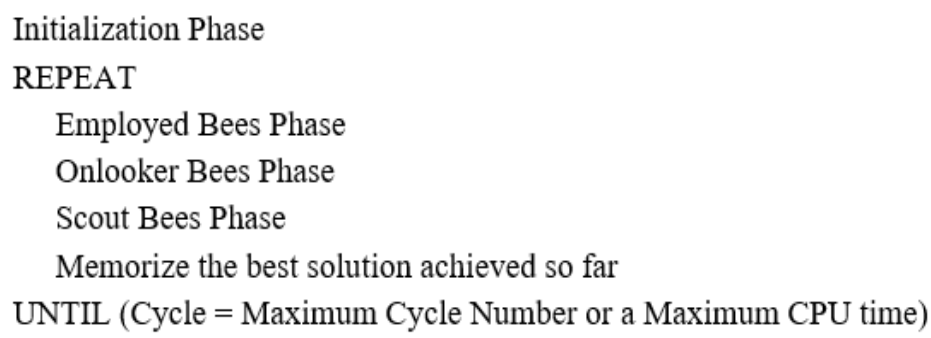

\section{METODE PENELITIAN}

Dalam metode penelitian ini akan diuraikan meliputi metode pendekatan sistem, pengembangan sistem, lokasi penelitian dan teknik pengumpulan data.

\subsection{Metode Pendekatan Sistem}

Metode pendekatan sistem pada penelitian ini yaitu menggunakan pendekatan berorientasi objek dengan tools pemodelan menggunakan UML.

\subsection{Tahapan Penelitian}

Tahapan-tahapan penelitian yang dilakukan berdasarkan metode pengembangan sistem model prototipe di bawah ini :

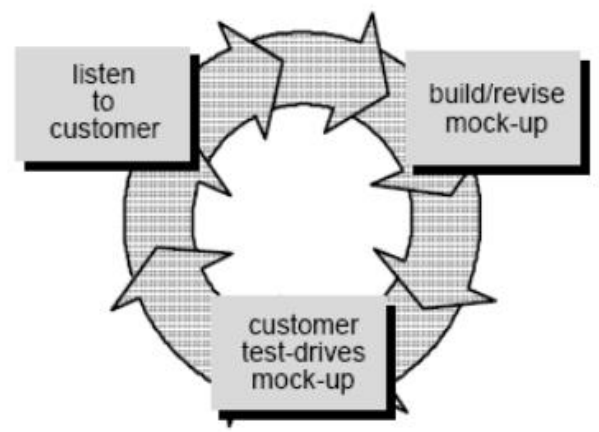

Gambar 1. Model Prototipe [3]

Berikut ini tahapan kegiatan dari model prototipe:

Listen to customer. Kegiatan pada tahap ini yaitu menganalisis sistem yang sedang berjalan sekaligus menggali informasi terikait kebutuhan pengguna terhadap sistem informasi jadwal kuliah. Pada tahap ini menghasilkan model sistem informasi jadwal kuliah yang sedang berjalan.

Build or revise Mock-up. Pada tahap ini dilakukan perancangan sistem informasi jadwal kuliah dengan menggunakan algoritma ABC (Artificial Bee Colony) yang meliputi perancangan funsionalitas sistem informasi jadwal kuliah, perancangan database, perancangan antar muka dan membuat pemodelan penerapan algoritma ABC pada penjadwalan kuliah.

\subsection{Lokasi Penelitian}

Pada penelitian ini kami mengambil studi kasus di program Studi Ilmu Komunikasi, Universitas Komputer Indonesia yang beralamat di jalan dipatiukur No 102-118 Bandung.

\subsection{Teknik Pengumpulan Data}

Ada dua sumber data yang digunakan pada penelitian ini yaitu sebagai berikut:

1) Sumber Data Primer 
Sumber data primer diperoleh dengan menggunakan dua cara yaitu :

a. Observasi

Penulis melakukan observasi untuk mengamati keadaan fisik atau lokasi penelitian yaitu program Studi Ilmu Komunikasi.

b. Wawancara

Untuk mendapatkan data yang diperlukan, kami mewawancarai sekretaris dan sekretariat Program Studi Ilmu Komunikasi.

2) Sumber Data Sekunder

Data sekunder didapatkan dengan teknik dokumentasi. Dokumentasi adalah kegiatan mengumpulkan dokumen-dokumen yang terkait dengan obyek penelitian. Dokumen yang dikumpulkan seperti jadwal kuliah, berita acara perkuliahan, data ruang, data kelas, data dosen dan kurikulum.

\section{IV.HASIL DAN PEMBAHASAN}

\subsection{Hasil Penelitian}

Penelitian ini menghasilkan gambaran sistem yang sedang berjalan, gambaran sistem informasi jadwal kuliah yang diusulkan dan model penerapan algoritma $\mathrm{ABC}$ pada sistem informasi jadwal kuliah. Berikut ini penjelasan hasil penelitian sesuai dengan langkah langkah pada metode pengembangan sistem model prototipe.

\subsubsection{Listen to Customer}

Untuk mendapatkan informasi yang lengkap terkait kebutuhan pengguna sistem informasi jadwal kuliah, kami melakukan wawancara dengan sekretaris dan sekretariat. Kemudian dilanjutkan membuat pemodelan sistem informasi jadwal kuliah yang berjalan. Adapun solusi yang ditawarkan terkait kebutuhan pengguna yaitu membangun sistem informasi jadwal kuliah dengan algoritma ABC (Artificial Bee Colony) dengan tujuan dapat terwujud sebuah aplikasi yang dapat melakukan penjadwalan secara otomatis dan menghasilkan jadwal yang optimal. Gambaran proses penjadwalan yang sedang berjalan dapat dilihat pada gambar 3 .

\subsubsection{Build or revise Mock-up}

Pada tahap Build or revise mock-up ini akan dijelaskan hasil perancangan fungsionalitas aplikasi , perancangan database, perancangan antar muka dan model penerapan algoritma $\mathrm{ABC}$ pada penjadwalan kuliah.

\subsubsection{Rancangan Fungsionalitas Aplikasi}

Fungsionalitas aplikasi akan digambarkan melalui use case diagram dan activity diagram.

1) Use Case Diagram

Fungsionalitas sistem informasi jadwal kuliah dapat dilihat pada gambar 2:

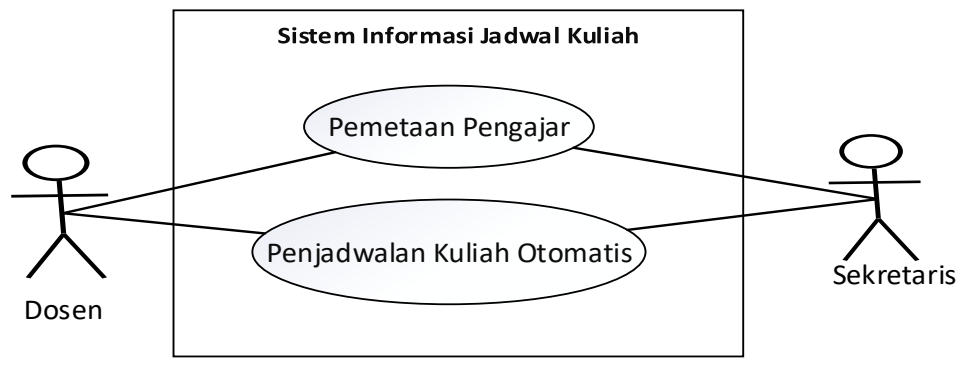

Gambar 2. Use Case Sistem Informasi Jadwal Kuliah 


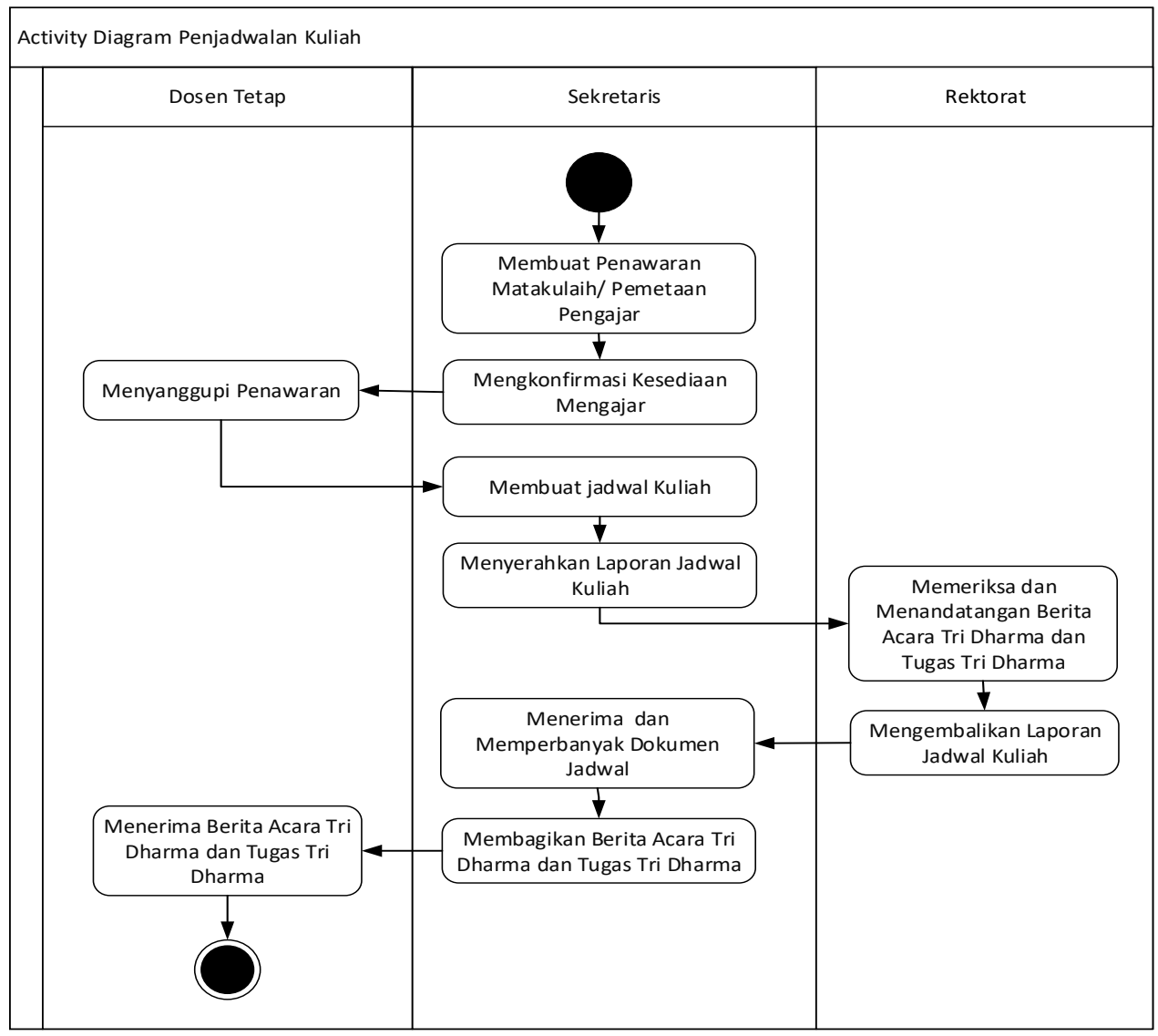

Gambar 3. Activity Diagram Penjadwalan Kuliah yang sedang berjalan

\section{2) Activity Diagram}

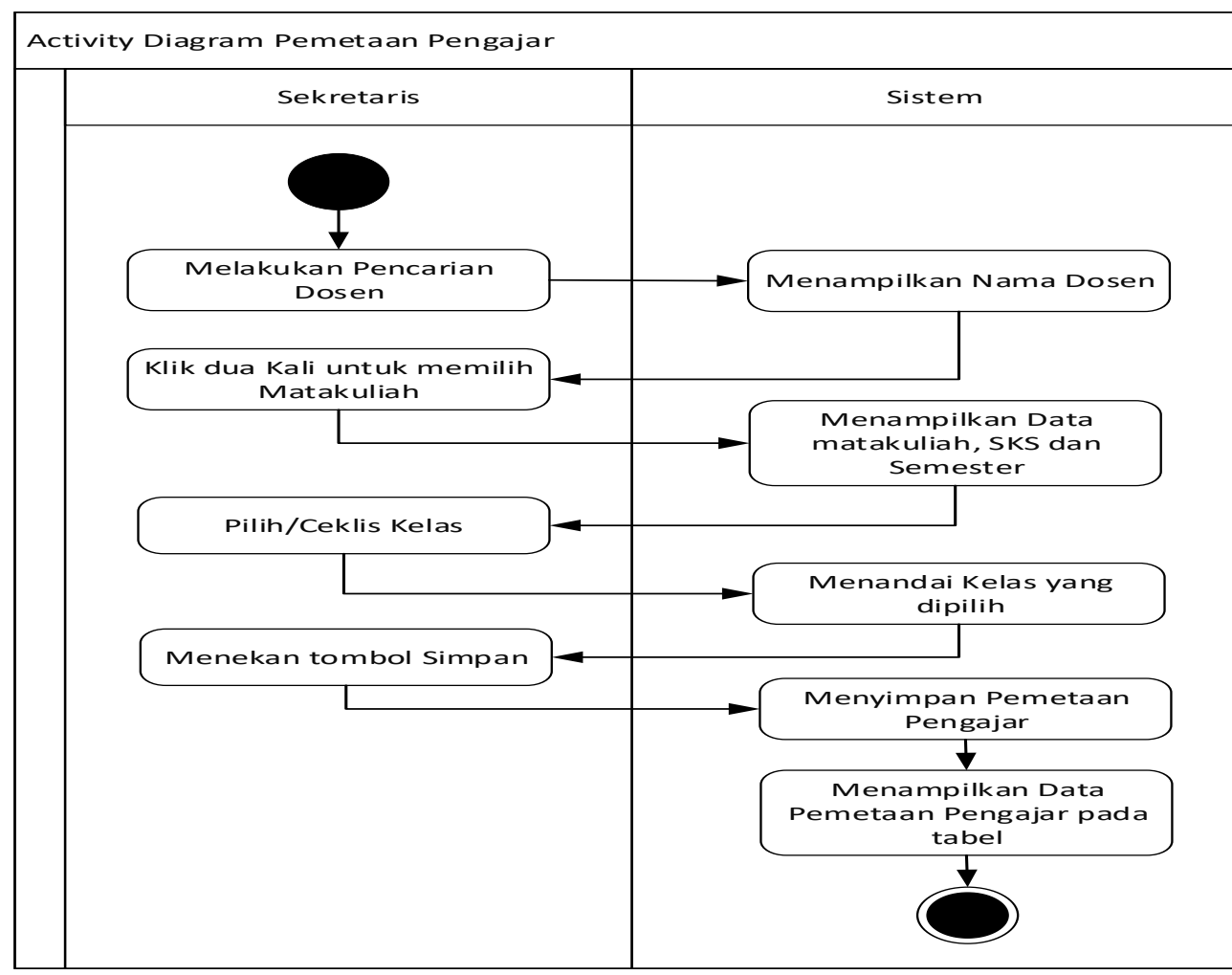

Gambar 4. Activity Diagram Pemetaan Pengajar 


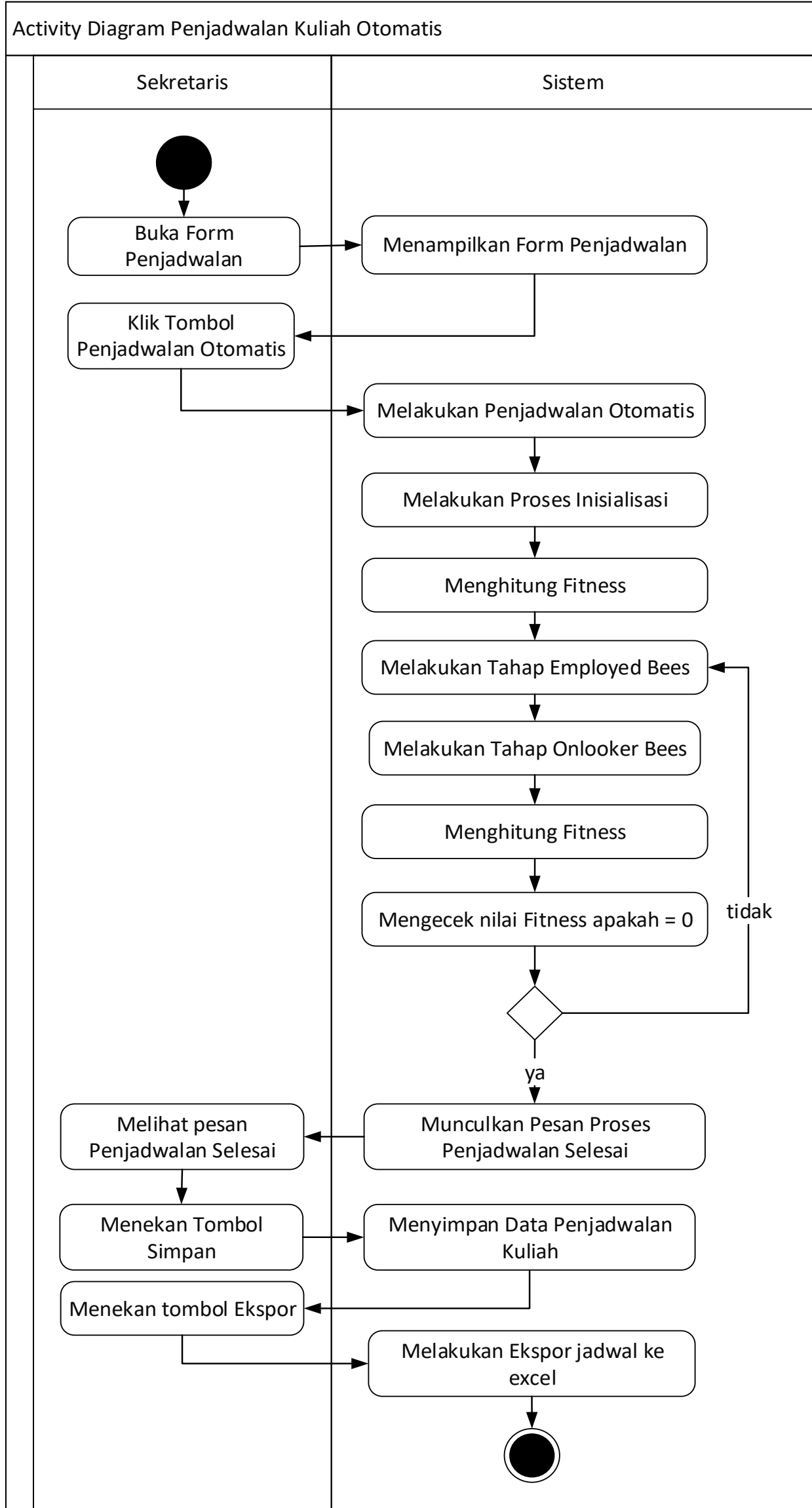

Gambar 5. Activity Diagram Penjadwalan Kuliah Otomatis 


\subsubsection{Perancangan Database}

Berikut ini rancangan database Sistem Informasi Jadwal Kuliah:

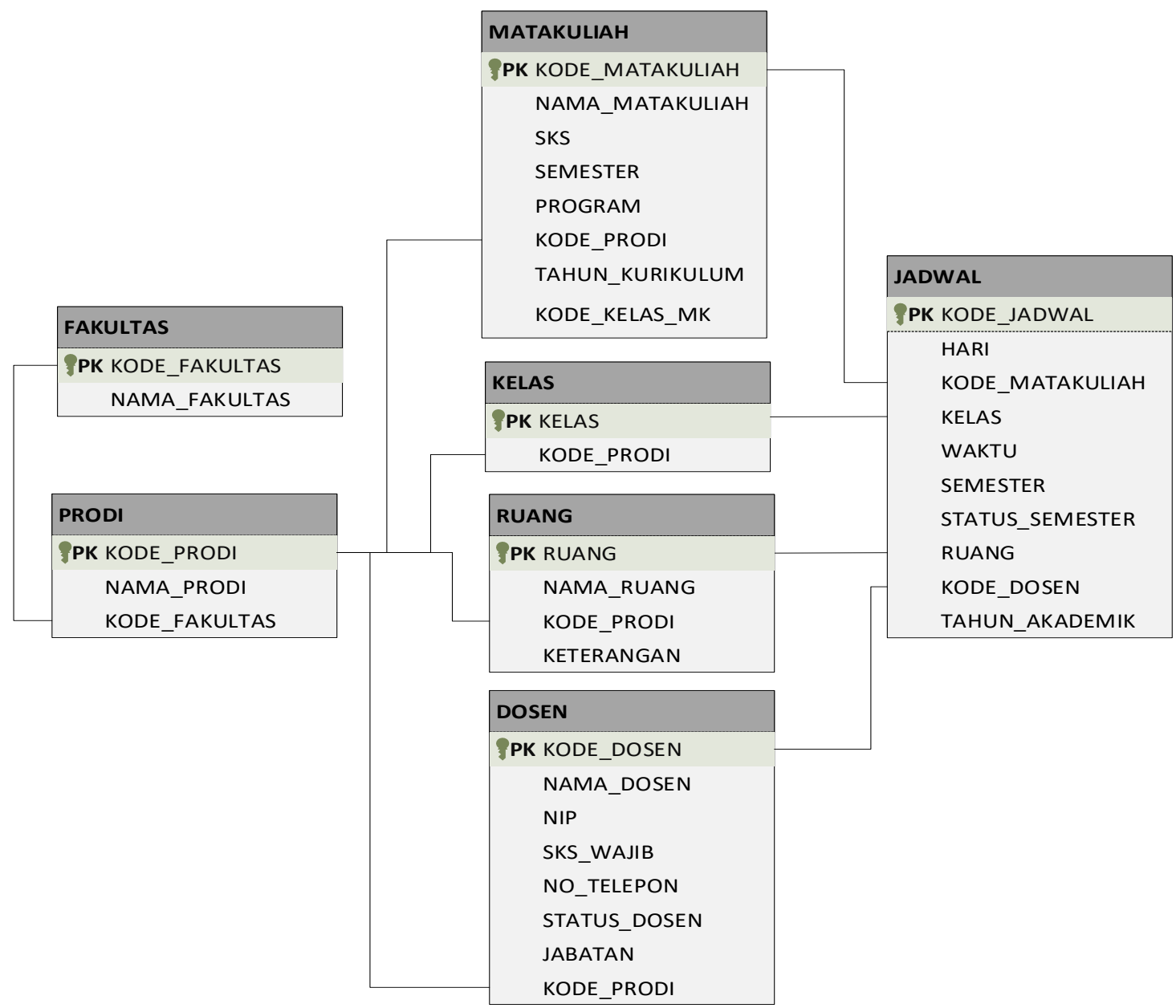

Gambar 6. Rancangan Database Sistem Informasi Jadwal Kuliah

\subsubsection{Perancangan Antar muka}

Berikut ini form penjadwalan kuliah otomatis menggunakan algoritma $\mathrm{ABC}$ :

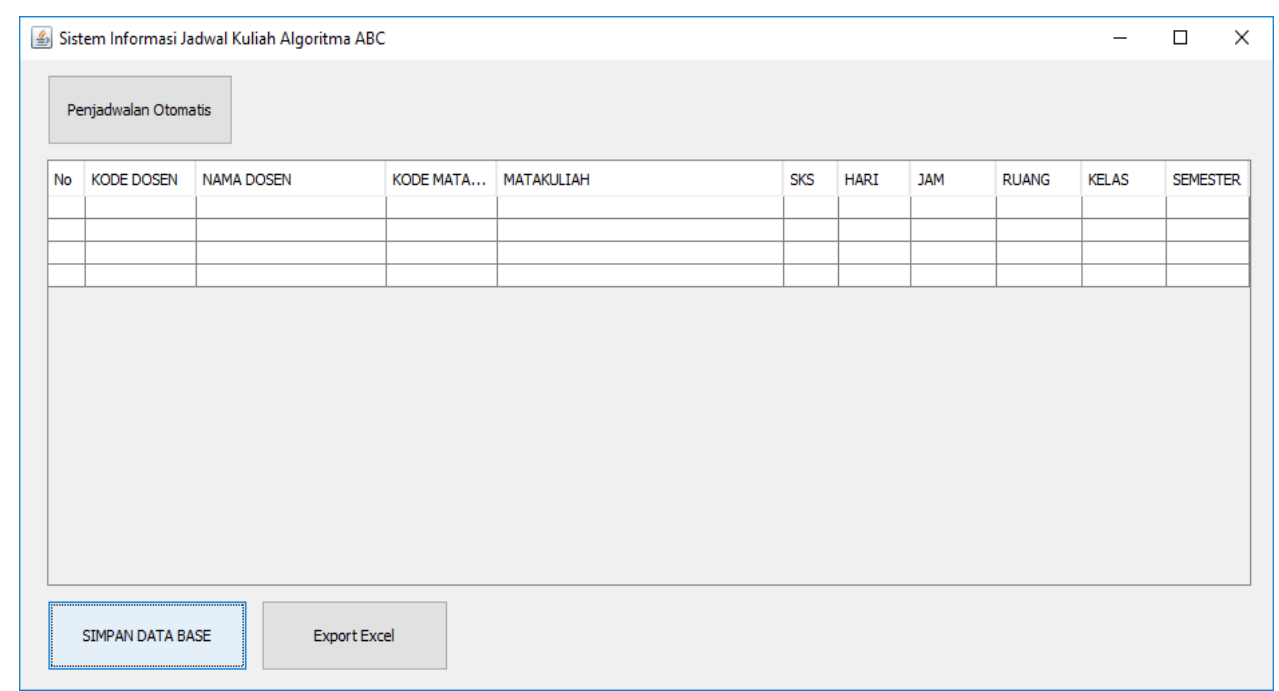

Gambar 7. Rancangan Form Penjadwalan Kuliah Otomatis 


\subsubsection{Pemodelan Algoritma ABC (Artificial Bee Colony)}

Hasil pemodelan penerapan Algoritma ABC pada Sistem Informasi Jadwal Kuliah dapat dilihat pada gambar 8 di bawah ini.

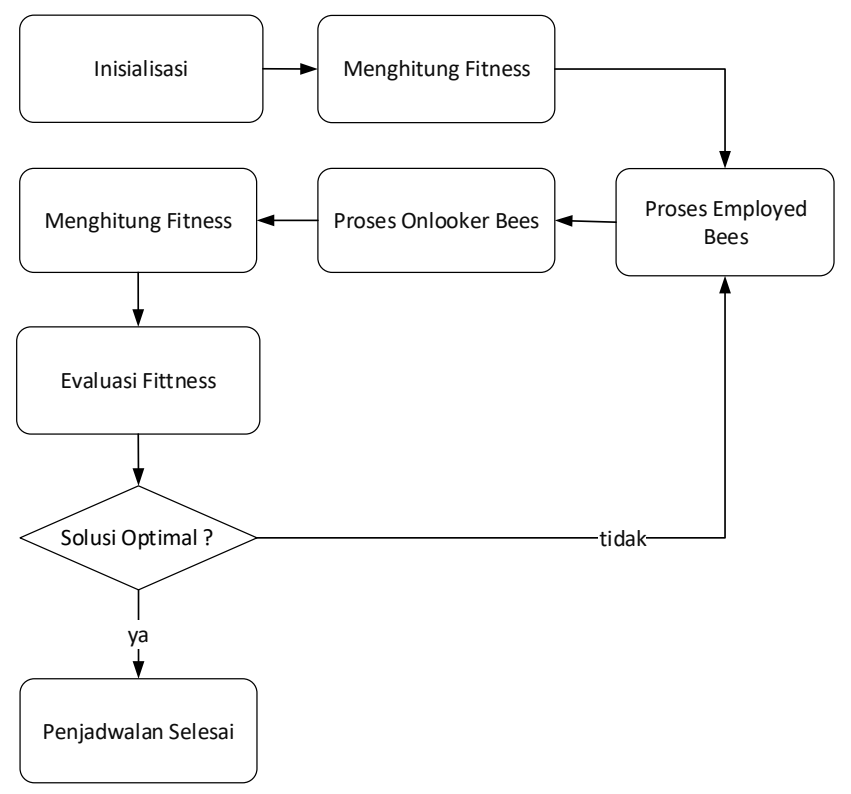

Gambar 8. Model Sistem Informasi Jadwal Kuliah Menggunakan Algoritma ABC

Pada penjadwalan kuliah ini kami membuat asumsi sebagai berikut ini:

1) Colony adalah keseluruhan pemetaan pengajar (dosen, matakuliah, kelas).

2) Lebah adalah setiap satu pemetaan pengajar (dosen, matakuliah, kelas).

3) Sumber makanan (food source) adalah pasangan ruang hari dan jam.

4) Kegiatan pemetaan pengajar atau pemasangan dosen, matakuliah dan kelas dilakukan oleh sekretaris, sehingga proses penjadwalan secara otomatis hanya untuk memasangkan hasil plot dosen dengan ruang, hari dan jam.

5) Penjadwalan kuliah ini untuk konsep kelas matakuliah, sehingga tidak menangani bentrok antar kelas itu sendiri.

6) Durasi setiap slot jam semua ditetapkan 3 sks.

7) Penjadwalan hanya untuk perkuliahan teori di ruang kelas.

8) Hari untuk penjadwalan kuliah adalah senin-sabtu (6 hari).

9) Disediakan 4 slot jam dalam sehari.

10) Slot jam ke 3 hari jumat tidak dijadwalkan.

11) Hari sabtu hanya menyediakan 3 slot jam.

12) Total slot jadwal (jumlah ruang $x$ jumlah hari $x$ jumlah slot jam) harus lebih banyak dari data plot dosen yang akan dijadwalkan.

\subsubsection{Batasan / Constraints}

Pada penjadwlan ini batasan/constraints yang harus terpenuhi adalah sebagai berikut:

1) Dilarang dosen dijadwalkan 2 (dua) atau lebih pada hari dan jam yang sama

2) Dilarang ada 2 atau lebih jadwal pada ruang hari dan jam yang sama

\subsubsection{Tahap Inisialisasi / Scout Bees (Eksplorasi)}


Pada penjadwalan ini inisialisasi adalah proses memasangkan secara acak semua lebah/ data pemetaan pengajar (dosen, matakuliah, kelas) dengan sumber makanan (ruang, hari dan jam). Masing masing nilai ruang, hari dan jam dibuat secara acak dengan fungsi random, sehingga pasangan lebah dengan sumber makanan terbentuk secara acak. Contoh insialisasi dapat dilihat pada tabel 1 .

Tabel 1. Contoh Inisialisasi

\begin{tabular}{|c|c|c|c|c|c|c|}
\hline & Dosen & MK & Kelas & Ruang & Hari & Jam \\
\hline J1 & 2 & 1 & 5 & 4 & 2 & 1 \\
\hline $\mathrm{J} 2$ & 5 & 2 & 2 & 1 & 4 & 2 \\
\hline $\mathrm{J} 3$ & 5 & 3 & 4 & 1 & 4 & 2 \\
\hline J4 & 1 & 4 & 3 & 4 & 2 & 1 \\
\hline J5 & 4 & 5 & 1 & 2 & 4 & 2 \\
\hline J6 & $\ldots$ & $\ldots$ & $\ldots$ & $\ldots$ & $\ldots$ & $\ldots$ \\
\hline
\end{tabular}

\subsubsection{Menghitung Fitness}

Pada penjadwalan ini fungsi fitness dihitung dengan menjumlahkan bentrok DHJ (Dosen, Hari, Jam) dengan bentrok RHJ (Ruang, Hari, Jam).

\section{Fitness=Bentrok DHJ+Bentrok RHJ}

Penghitungan fitness dilakukan untuk menentukan baik tidaknya pasangan lebah dengan sumber makanan dan untuk kasus penjadwalan kuliah ini satu sumber makanan hanya boleh dimiliki oleh satu lebah. Tabel 2 dan 3 di bawah ini menjelaskan contoh jadwal yang bentrok.

Tabel 2. Contoh Bentrok DHJ

\begin{tabular}{|c|c|c|c|c|c|c|}
\hline & Dosen & MK & Kelas & Ruang & Hari & Jam \\
\hline J1 & 2 & 1 & 5 & 4 & 2 & 1 \\
\hline $\mathrm{J} 2$ & 5 & 2 & 2 & 1 & 4 & 2 \\
\hline J3 & 5 & 3 & 4 & 1 & 4 & 2 \\
\hline J4 & 1 & 4 & 3 & 4 & 2 & 1 \\
\hline J5 & 4 & 5 & 1 & 2 & 4 & 2 \\
\hline Jn & $\ldots$ & $\ldots$ & $\ldots$ & $\ldots$ & $\ldots$ & $\ldots$ \\
\hline
\end{tabular}

Tabel 3. Contoh Bentrok RHJ

Dosen MK Kelas Ruang Hari Jam

\begin{tabular}{l|c|c|c|c|c|c|}
\cline { 2 - 7 } J1 & 2 & 1 & 5 & 4 & 2 & 1 \\
\cline { 2 - 7 } J2 & 5 & 2 & 2 & 1 & 4 & 2 \\
\cline { 2 - 7 } J3 & 5 & 3 & 4 & 1 & 4 & 2 \\
\cline { 2 - 7 } J4 & 1 & 4 & 3 & 4 & 2 & 1 \\
\cline { 2 - 7 } J5 & 4 & 5 & 1 & 2 & 4 & 2 \\
\cline { 2 - 7 } Jn & $\ldots$ & $\ldots$ & $\ldots$ & $\ldots$ & $\ldots$ & $\ldots$ \\
\cline { 2 - 7 } & & & &
\end{tabular}

Berdasarkan tabel 2 dan 3 dapat dihitung total fitness dari seluruh fitness jadwal kuliah, contoh hasil perhitungan total fitness dapat dilihat pada tabel 4 .

Tabel 4. Contoh hasil perhitungan fitness/bentrok

\begin{tabular}{cccc}
\hline No & Bentrok DHJ & Bentrok RHJ & Fitness \\
\hline J1 & 0 & 1 & 1 \\
\hline J2 & 1 & 1 & 2 \\
\hline J3 & 1 & 1 & 2 \\
\hline J4 & 0 & 1 & 1 \\
\hline J5 & 0 & 0 & 0 \\
\hline Jn & $\ldots$ & $\ldots$ & $\ldots$ \\
\hline
\end{tabular}


Berdasarkan tabel 4, jika diasumsikan jadwal J5 dan seterusnya tidak ada yang bentrok maka total bentrok/fitness $=6$.

\subsubsection{Tahap Employed Bees (Evaluasi dan Seleksi)}

Dianalogikan dengan tugas employee bees, sistem informasi penjadwalan kuliah akan memilih/menyeleksi jadwal yang memiliki nilai fitnees terbaik. Dilihat dari tabel 1 , maka jadwal yang terbaik adalah yang memiliki nilai fitness 0 . Untuk implementasinya jadwal dengan fitness 0 akan ditandai untuk tidak dilakukan perubahan/perbaikan di tahap selanjutnya. Diasumsikan data J5 dan seterusnya yang memiliki fitness terbaik.

\subsubsection{Tahap Onlooker Bees (Eksploitasi)}

Pada tahap eksploitasi ini sistem informasi penjadwalan kuliah akan melakukan perbaikan kualitas fitness jadwal tersebut dengan melakukan random untuk nilai ruang, hari dan jam. Adapun pasangan nilai ruang, hari, jam yang diacak, dipastikan belum terjadwalkan. Setelah melakukan perubahan nilai ruang, hari dan jam maka akan dihitung kembali nilai fitness dari masing-masing jadwal. Contoh hasil perbaikan jadwal secara random dapat dilihat pada tabel 5.

Tabel 5. Contoh hasil perbaikan secara random

\begin{tabular}{|c|c|c|c|c|c|}
\hline Dosen & MK & Kelas & Ruang & Hari & Jam \\
\hline $\mathrm{J} 1$ & 1 & 5 & 2 & 5 & 2 \\
\hline $\mathrm{J} 2$ & 2 & 2 & 3 & 5 & 1 \\
\hline $\mathrm{J} 3$ & 3 & 4 & 4 & 2 & 2 \\
\hline J4 & 4 & 3 & 5 & 4 & 3 \\
\hline J5 & 5 & 1 & 2 & 4 & 2 \\
\hline$\ldots$ & $\ldots$ & $\ldots$ & $\ldots$ & $\ldots$ & $\ldots$ \\
\hline
\end{tabular}

Langkah selanjutnya adalah menghitung fitness kembali. Apabila nilai fitness masih ada yang lebih dari 0 maka akan mengulangi ke langkah tahap Employed Bees yakni menyeleksi jadwal yang terbaik.

\section{KESIMPULAN DAN SARAN}

Penelitian ini menghasilkan model sistem informasi jadwal kuliah menggunakan algoritma ABC. Model ini diharapkan dapat menjadi acuan dalam tahap membangun sistem informasi jadwal kuliah dengan proses penjadwalan otomatis yang dapat meminimalisir bentrok jadwal dengan proses penjadwalan yang cepat. Adapun saran untuk penelitian selanjutnya yaitu melakukan implementasi / membangun aplikasi sistem informasi jadwal kuliah serta membuat penjadwalan dengan konsep kelas angkatan sehingga ada proses pengecekan terhadap bentrok antarkelas itu sendiri.

\section{UCAPAN TERIMA KASIH}

Kami mengucapkan terimakasih yang sebesar-besarnya kepada Direktorat Riset dan Pengabdian Masyarakat, Direktorat Jenderal Penguatan Riset dan Pengembangan, Kementerian Riset Teknologi dan Pendidikan Tinggi yang sudah memberikan dana hibah penelitian tahun anggaran 2018 untuk membiayai penelitian ini.

\section{DAFTAR PUSTAKA}

[1] E. K. Kendall dan E. J. Kendall, Systems Analysis and Design, 7th ed. New Jersey: Pearson Prentice Hall, 2008.

[2] J. Febrian, Kamus Komputer dan Teknologi Informasi. Bandung: Informatika, 2007.

[3] H. Al Fatta, Analisis Dan Perancangan Sistem Informasi Untuk Keunggulan Bersaing Perusahaan Dan Organisasi Modern. Yogyakarta: Andi, 2007. 
[4] J. Hutahaean, Konsep Sistem Informasi. Yogyakarta: Deepublish, 2014.

[5] E. Herjanto, Manajemen Operasi. Jakarta: Grasindo, 2007.

[6] P. B. Kemdikbud, Kamus Besar Bahasa Indonesia. https://kbbi.web.id/kuliah, 2012.

[7] R. F. Nugroho dan M. Ayub, "Penerapan Algoritma Artificial Bee Colony dalam Aplikasi Penjadwalan Pelajaran untuk Sekolah Menengah Pertama," J. Inform., vol. 9, no. 1, hal. 117, Mar 2013. 